\title{
Wpływ wyników i dokonań MŚP na rozwój społeczno-ekonomiczny kraju
}

\section{Impact of SME Results and Achievements on the Socio-Economic Development of the Country}

Streszczenie: Małe i średnie przedsiębiorstwa (MŚP) to podmioty o wyodrębnionej charakterystyce i wyraźnie określonych granicach działalności. Tworzą one jeden z najistotniejszych sektorów stymulujących czynniki rozwojowe polskiej gospodarki. Jej kondycja stale zależna jest od tego właśnie sektora, który swoim istnieniem stymuluje procesy zachodzące w systemie gospodarczym. Głównym celem niniejszego opracowania jest ocena wyników MŚP na podstawie danych zawartych w sprawozdaniach finansowych za lata 2010-2016 z wykorzystaniem metody $\bar{r}$ średniego tempa wzrostu (Timofiejuk, 1980a). Z istoty przedstawionej metody $\bar{r}$ wynika, że tylko początkowy i końcowy wyraz szeregu chronologicznego decyduje o wartości liczbowej średniego tempa wzrostu. Faktyczny szereg chronologiczny można traktować jako „postęp geometryczny o zmiennym ilorazie”. Dla realizacji podjętego tematu przyjęto tezę zakładającą, że: obiektywna i umiejętnie przeprowadzona ocena wyników finansowych przeszłych zdarzeń jest podstawą do podejmowania trafnych decyzji w przyszłości, co może sprzyjać rozwojowi ekonomiczno-społecznemu kraju.

\begin{abstract}
Small and medium enterprises are entities with distinct characteristics and clearly defined operational limits. For the Polish economy, it is one of the most important sectors stimulating development factors. Its condition is constantly dependent on this sector, which by its existence stimulates the processes taking place in the economic system. The main purpose of this study is to evaluate the results of SMEs based on the data contained in the financial statements for 2010-2016 using the method of $\bar{r}$ average growth rate (Timofiejuk, 1980). It is apparent from the nature of the presented method ri that only the initial and final expression of the chronological series determines the numerical value of the average growth rate. The actual chronological series can be considered as "geometric progress with a variable ratio". For the implementation of the subject, the following thesis was assumed: objective and skilful assessment of the financial results of past events is the basis for making accurate decisions in the future, which may favour the economic and social development of the country.
\end{abstract}

Słowa kluczowe: analiza; biznes; finanse; sprawozdania

Keywords: analysis; business; finance; reports 
Otrzymano: 14 października 2019

Received: 12 October 2019

Zaakceptowano: 22 marca 2020

Accepted: 22 March 2020

\section{Sugerowana cytacja/Suggested citation:}

Nesterowicz, R. (2020). Wpływ wyników i dokonań MSP na rozwój społeczno-ekonomiczny kraju. Przedsiębiorczość - Edukacja [Entrepreneurship - Education], 16(1), 302-310. doi: 10.24917/20833296.161.24

\section{Wstęp}

Małe i średnie przedsiębiorstwa (MŚP) to podmioty o wyodrębnionej charakterystyce i wyraźnie określonych granicach działalności. Z tego względu przy próbie podania definicji i określenia znaczenia MŚP w gospodarce należy w pierwszej kolejności skupić się na pojęciu przedsiębiorstwa i przedsiębiorczości. Przedsiębiorczość jest cechą działania człowieka, oznaczającą zdolność do samodzielnej i indywidualnej pracy, by uzyskać korzyści, zyski i pozycję w systemie gospodarczym. Prowadzenie przedsiębiorstwa oraz samo pojęcie przedsiębiorcy od 2 lipca 2004 r. określane były przez ustawę o swobodzie działalności gospodarczej w następujący sposób: „Działalnością gospodarczą jest zarobkowa działalność wytwórcza, budowlana, handlowa, usługowa oraz poszukiwanie, rozpoznawanie i wydobywanie kopalin ze złóż, a także działalność zawodowa, wykonywana w sposób zorganizowany i ciągły" (Ustawa $z$ dnia 2 lipca 2004 roku..., art. 2). Natomiast „Przedsiębiorcą w rozumieniu ustawy jest osoba fizyczna, osoba prawna i jednostka organizacyjna niebędąca osobą prawną, której odrębna ustawa przyznaje zdolność prawną - wykonująca we własnym imieniu działalność gospodarczą" (Ustawa z dnia 2 lipca 2004 roku..., art. 4.1). 6 marca 2018 r. weszła w życie nowa ustawa. Jest nią Prawo przedsiębiorców, które zastąpiło po prawie 14 latach ustawę o swobodzie działalności gospodarczej oraz jednocześnie pojęcie przedsiębiorstwa zredukowało do prostego zdania: „Działalnością gospodarczą jest zorganizowana działalność zarobkowa, wykonywana we własnym imieniu i w sposób ciągły" (Ustawa $z$ dnia 6 marca 2018 roku..., art. 3).

Biorąc pod uwagę te dwa pojęcia, decyzja o założeniu przedsiębiorstwa opiera się na celach, którymi są rozwój podmiotu oraz osiągnięcie zysku. By do tego doprowadzić, jednostka zarządzająca musi wykazywać odpowiednie działania, takie chociażby, jak: przyjęcie sprecyzowanego planu postępowania, analizowanie i właściwe określenie sytuacji na rynku, szacowanie szans i zagrożeń, liczenie się z konkurencją, czy wreszcie - sprawne podejmowanie trafnych decyzji przy aktualnym poziomie ryzyka. Tym samym przedsiębiorczością można nazwać odpowiednie zachowanie rynkowe, podejmowane w celu osiągnięcia zamierzonych efektów działania. Aby jednak zrozumieć przedsiębiorczość i jej rolę w aspekcie rozwoju społeczno-ekonomicznego i kulturowego, niezbędna jest odpowiednia edukacja w tym zakresie.

Sektor małych i średnich przedsiębiorstw charakteryzuje się dynamicznym podejściem do otoczenia. Firmy te są w stanie najszybciej zareagować na rodzące się potrzeby oraz preferencje ewentualnych klientów, dlatego też są mobilne w angażowaniu środków finansowych w różne branże. Przedsiębiorstwa te są także w stanie kreować nową wartość dla potencjalnych nabywców, poświęcić na to konieczny czas i wysiłek oraz akceptować pewien poziom ryzyka finansowego i operacyjnego. Bardzo często działają one 
na podstawie produkcji opartej nie na ekonomii skali, ale na ciągłym poszukiwaniu okazji rynkowych. Oznacza to, że poszukują dla siebie pewnych nisz rynkowych, w których mogą aktywnie działać i nie są zagrożone ze strony konkurencji, czyli dużych przedsiębiorstw (Mikołajczyk, 2007).

Sektor małych i średnich przedsiębiorstw aktywizuje także rozwój regionalny i lokalny oraz rozwija nowe inicjatywy sprzyjające łagodzeniu bezrobocia w całej gospodarce i gospodarce poszczególnych regionów. W ukształtowanej zaś gospodarce rynkowej sektor ten pełni funkcję komplementarną w stosunku do dużych firm i sektora publicznego, a także stanowi zaplecze kooperacyjne i wspomagające funkcjonowanie dużych korporacji. Uważa się, że małe i średnie przedsiębiorstwa mogą uzyskać przewagę nad dużymi podmiotami, szczególnie w sytuacjach szybkiej reakcji na zmieniające się warunki otoczenia, otwarcia na wykorzystanie innowacji, łatwego wchodzenia w układy korporacyjne, przedsiębiorczego wykorzystywania różnego typu szans i okazji rynkowych, szybkich przepływów informacji, większej konkurencyjności oraz działalności opartej na zaspokajaniu konkretnych potrzeb lokalnego rynku (Stawasz, 2006).

Małe i średnie przedsiębiorstwa to przede wszystkim niezależne firmy. Mogą one podejmować współpracę, a nawet rywalizować z podmiotami plasującymi się na wyższym poziomie pod względem rozwoju działalności, a także przystosowywać swoje zasady i modernizować sposoby kierowania do reguł większych przedsiębiorstw.

Celem niniejszego opracowania jest przedstawienie wyników i dokonań sektora MŚP oraz jego roli w rozwoju społeczno-ekonomicznym kraju. Badaniom poddano majątek i źródła finansowania tych przedsiębiorstw oraz wybrane wskaźniki finansowe, wykorzystując w tym celu metodę ṛ średniego tempa wzrostu opracowaną przez prof. I. Timofiejuka. Według przedstawionej metody $\overline{\mathrm{r}}$, tylko początkowy i końcowy wyraz szeregu chronologicznego decyduje o wartości liczbowej średniego tempa wzrostu. Faktyczny szereg chronologiczny można traktować jako „postęp geometryczny o zmiennym ilorazie”.

W realizacji podjętego tematu przyjęto tezę badawczą zakładającą, iż umiejętnie przeprowadzona ocena wyników finansowych przeszłych zdarzeń gospodarczych jest podstawą do podejmowania trafnych decyzji w przyszłości, co może sprzyjać rozwojowi społeczno-ekonomicznemu kraju.

Opracowanie ma charakter teoretyczno-empiryczny. Materiałem źródłowym wykorzystanym do analizy była sprawozdawczość przedsiębiorstw publikowana przez GUS i PARP. Dane statystyczne prezentujące wyniki ekonomiczne małych i średnich przedsiębiorstw stanowiły podstawę oceny finansowej tego sektora przedsiębiorstw i dowiodły przy tym o jego znaczeniu w rozwoju gospodarczym kraju.

\section{Sektor MŚP i jego rola w rozwoju społeczno-ekonomicznym kraju}

Przedsiębiorstwa z sektora MŚP w swym funkcjonowaniu odznaczają się pewnymi specyficznymi cechami, które odróżniają je od dużych firm (Matejun, Szymańska, 2012). Warunkuje to zarówno zakres, jak i rodzaj działalności, ale przede wszystkim - model jej finansowania. W początkowej fazie działalności małe i średnie przedsiębiorstwa wykorzystują głównie środki własne właściciela, jego rodziny i znajomych, zaś w fazie rozwojowej - środki własne firmy pochodzące $\mathrm{z}$ wypracowanego zysku.

Małe i średnie przedsiębiorstwa niezmiennie są wymieniane jako główna siła napędowa wzrostu w równej mierze poszczególnych gospodarek krajowych, jak i całej Unii 
Europejskiej. Jednocześnie podkreśla się znaczenie przedsiębiorczości, której MŚP są nośnikami już od lat 80 . XX w.

Sektor MŚP w Polsce dobrze się rozwija i prosperuje, dzięki czemu jest dla naszej gospodarki jednym z najistotniejszych sektorów stymulujących jej rozwój oraz zachodzące w niej procesy. Znaczenie MŚP bardzo dobrze widać na podstawie PKB, dochodów, które osiąga ten rodzaj podmiotów, ich produkcji oraz liczby pracowników i zmian w zatrudnieniu. Kolejną korzyścią jest ożywienie gospodarcze sektora MŚP, dzięki któremu powstają nowe miejsca pracy (Kołodziej-Hajdo, Surowiec, 2011). Aby tego dowieść, poniżej przedstawiono tabele 1 i 2 .

Tabela 1. Liczba przedsiębiorstw aktywnych w Polsce w latach 2010-2016 (w tys.)

\begin{tabular}{|c|c|c|c|c|}
\hline \multirow{2}{*}{ Rok } & \multirow{2}{*}{ Ogółem } & \multicolumn{3}{|c|}{ W tym } \\
\cline { 3 - 5 } & & małe & średnie & duże \\
\hline 2010 & 1727 & 52,6 & 15,8 & 3,2 \\
\hline 2011 & 1785 & 55,0 & 15,8 & 3,2 \\
\hline 2012 & 1795 & 57,1 & 15,5 & 3,2 \\
\hline 2013 & 1771 & 59,1 & 15,3 & 3,2 \\
\hline 2014 & 1843 & 59,2 & 15,5 & 3,4 \\
\hline 2015 & 1914 & 56,7 & 15,6 & 3,4 \\
\hline 2016 & 2013 & 57,2 & 15,4 & 3,6 \\
\hline 2017 & 2077 & 53,8 & 15,3 & 3,6 \\
\hline
\end{tabular}

Źródło: opracowanie własne na podstawie PARP (2019)

Analizując dane dotyczące liczby przedsiębiorstw ze względu na klasę wielkości, można zauważyć, że w okresie 2010-2017 udział poszczególnych grup ulegał niewielkim wahaniom i utrzymywał się na zbliżonym poziomie, choć porównując strukturę firm w 2017 r. do tej z 2010 r., widać nieznaczny wzrost udziału dużych przedsiębiorstw oraz spadek udziału firm średnich. W 2017 r. względem 2016 r. szczególnie zmniejszyła się liczba aktywnych przedsiębiorstw w grupie firm małych (o 0,9\%). Nadmienić przy tym należy, że polskie MŚP działają przede wszystkim w usługach i handlu (76,3\%), rzadziej zaś w budownictwie i przetwórstwie przemysłowym.

Istotny z punktu widzenia działalności gospodarczej jest również aspekt społeczny przejawiający się w tworzeniu miejsc pracy. Dla gospodarki jest to ważny punkt $\mathrm{z}$ listy korzyści, które wiążą się z pojawianiem nowych przedsiębiorstw na rynku. Należy jednak odróżniać terminy "pracujący” oraz „zatrudniony”. Pozornie uznaje się je za zbliżone, jednak w rzeczywistości ich znaczenie sporo się różni. Osobą pracującą nazywa się każdą osobę wykonującą pracę na rzecz firmy i pracodawcy, za którą to pracę otrzymuje ona wynagrodzenie przeważnie wypłacane według stawek godzinowych. Osobą zatrudnioną jest natomiast każdy pracownik, który podejmuje pracę na podstawie umowy, na czas określony lub nieokreślony. Generuje on stałą stawkę niezależnie od tego, czy w okresie rozliczeniowym jest praca do wykonania, czy też jej nie ma. Liczebność osób pracujących w latach 2010-2017 została przedstawiona w tabeli 2.

Na podstawie ustaleń z tabeli 2 można zauważyć, iż liczba osób pracujących w całym sektorze przedsiębiorstw i przeciętne zatrudnienie wykazywały w badanych latach pewne wahania. Wyraźna tendencja wzrostowa jest widoczna w obu analizowanych 
grupach od roku 2014. Fakt ten może świadczyć o rozwoju przedsiębiorczości w naszym kraju.

Tabela 2. Liczba osób pracujących i przeciętne zatrudnienie w sektorze przedsiębiorstw w latach 2010-2017 (w tys.)

\begin{tabular}{|c|c|c|}
\hline Rok & Liczba pracujących & Przeciętne zatrudnienie \\
\hline 2010 & 8859053 & 6495266 \\
\hline 2011 & 9028536 & 6595759 \\
\hline 2012 & 8937353 & 6545968 \\
\hline 2013 & 8898898 & 6428960 \\
\hline 2014 & 9145658 & 6544757 \\
\hline 2015 & 9395607 & 6679090 \\
\hline 2016 & 9692168 & 6804168 \\
\hline 2017 & 9860278 & 6892682 \\
\hline
\end{tabular}

Źródło: opracowanie własne na podstawie: PARP (2019)

\section{Średnie tempo zmian wybranych wyników finansowych dla sektora MŚP w Polsce}

Poziom przychodów kosztów oraz wyników finansowych przedsiębiorstw musi być przez nie stale kontrolowany i porównywany zarówno w czasie, jak i w przestrzeni. Istotne jest, by koszty nie przewyższały przychodów. Przedsiębiorstwa powinny systematycznie analizować i kontrolować swoją sytuację finansową. Takie działanie ma na celu przede wszystkim uniknięcia bankructwa i upadku przedsiębiorstwa, czyli utrzymanie jego prawidłowego funkcjonowania na rynku. Ważnym aspektem jest również działanie w kierunku maksymalizacji zysku, zwiększania swoich przychodów i minimalizacji kosztów, aby osiągać coraz lepsze efekty ekonomiczne. Istotne niewątpliwie w tym zakresie jest przeprowadzanie analizy finansowej. Pozwala ona na sformułowanie wniosków dotyczących funkcjonowania przedsiębiorstwa w przeszłości, a także stanowi bazę informacyjną wykorzystywaną przy podejmowaniu dotyczących przyszłości (Gad, 2015).

Koszty i przychody to dwa elementy wyniku finansowego, które decydują o tym, czy przedsiębiorstwo swoją działalność w danym roku zamknie zyskiem, czy ze stratą. Koszty z reguły pojawiają się na skutek działalności, której celem jest wypracowanie dodatniego wyniku finansowego (Kowalska, 2014).

Definicja przychodów jako pojęcia z dziedziny ekonomii i rachunkowości została przedstawiona w ustawie o rachunkowości (Ustawa z dnia 29 września 1994 roku..., art. 3.1, poz. 30).

Analiza wyników finansowych jest niezwykle ważnym działaniem, które pozwala na ocenę sprawności, płynności i sytuacji rozwojowej firmy. Jest ona niezbędna w kwestii dowiedzenia się, czy dany podmiot funkcjonuje prawidłowo i jak oddziałuje na ogół systemu gospodarczego. Dzięki złożoności wskaźników stosowanych do oceny finansowej, wykorzystać je można również do analizy całego sektora przedsiębiorstw. W tym przypadku będzie to sektor MŚP. Do przeprowadzenia analizy finansowej tego sektora wykorzystano dane GUS i PARP za lata 2010-2016. Ponadto zastosowano metodę ṛ średniego tempa wzrostu do ukazania średniego tempa zmian wybranych wyników i wskaźników dotyczących działalności sektora MŚP, co przedstawiono w tabeli 3. 


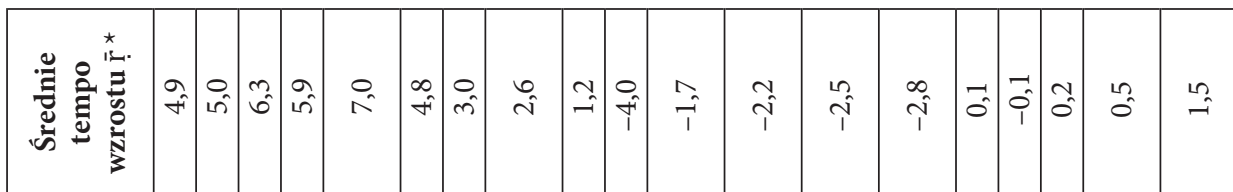

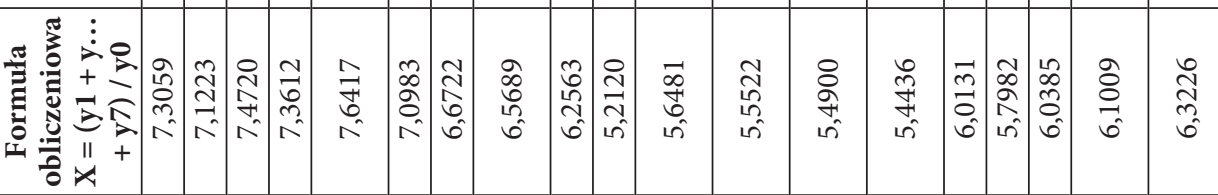

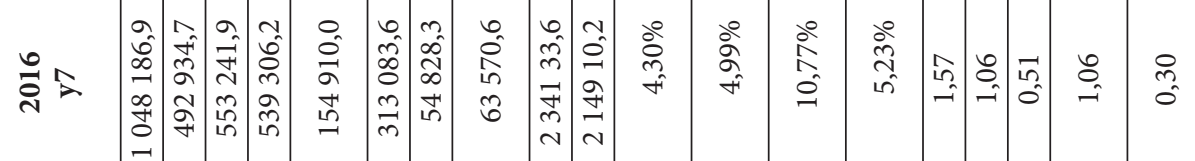

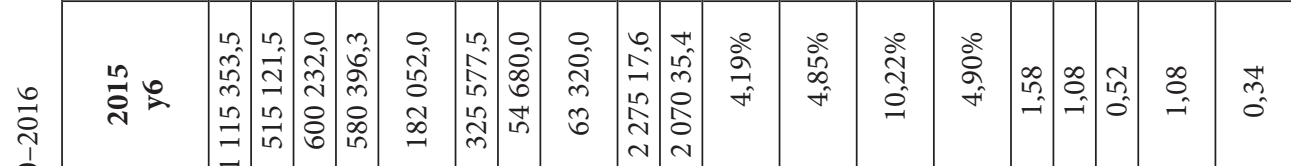

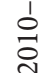

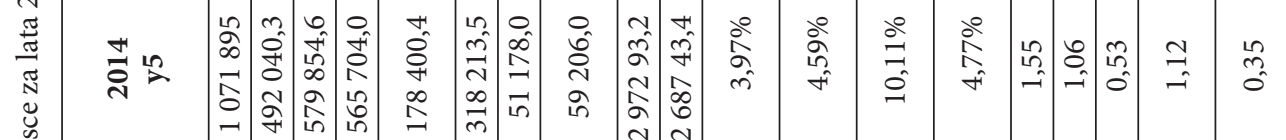

\begin{tabular}{c}
$\mathscr{u}$ \\
\hdashline
\end{tabular}

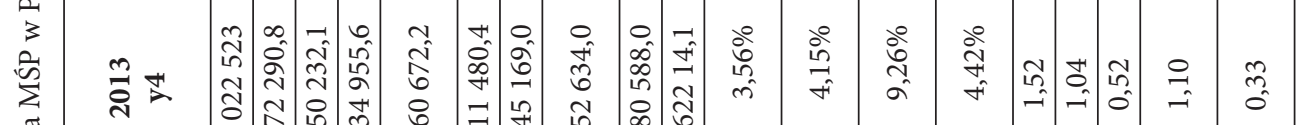

ำ

3

望

蒿

द

?

政

当

.

帘

望

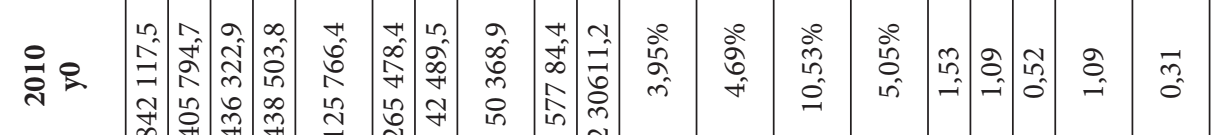

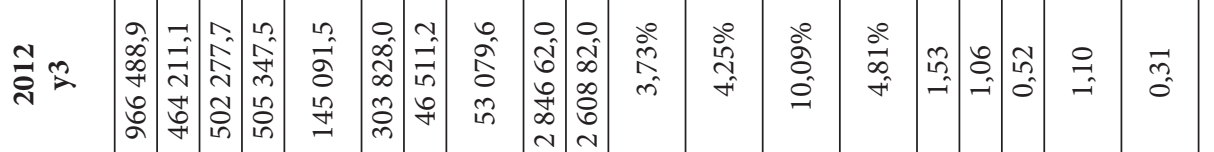

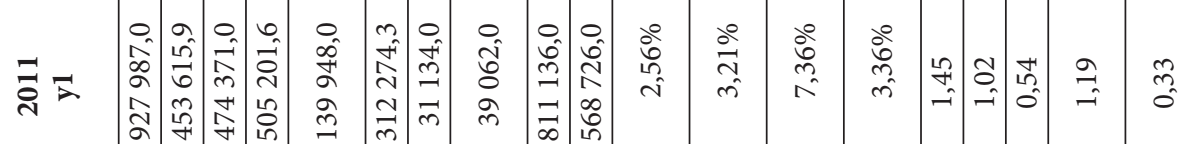

हี

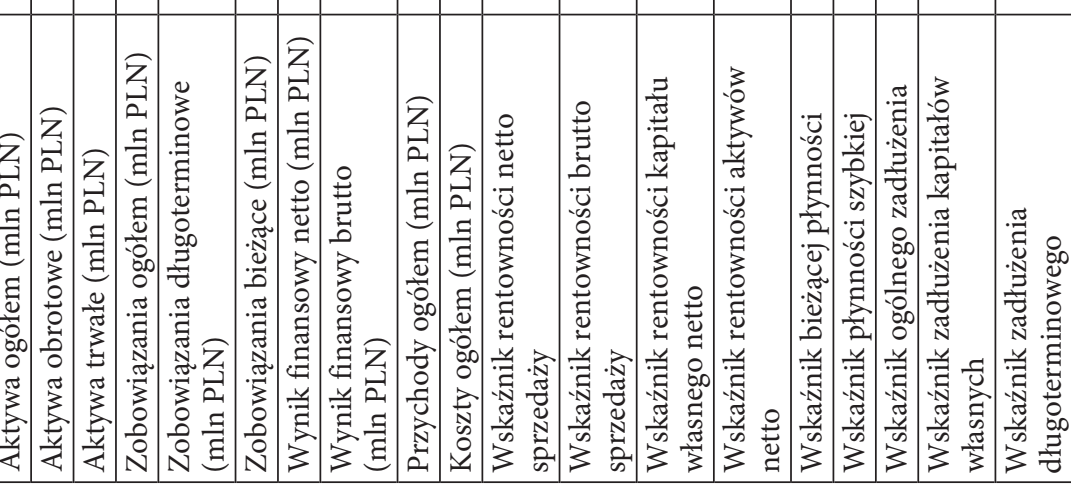

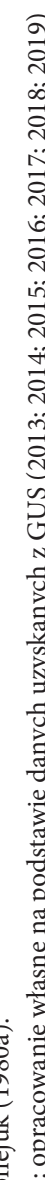


Z danych zawartych w tabeli wywnioskować można, że średnie tempo wzrostu aktywów trwałych wyniosło w okresie siedmiu badanych lat 6,3\%, natomiast aktywów obrotowych - 5\%. Analizując zobowiązania ustalono, że zobowiązania długoterminowe wykazały średnie tempo wzrostu na poziomie $7 \%$, natomiast zobowiązania bieżące $-4,8 \%$.

Uśrednione tempo wzrostu wyniku finansowego kształtowało się na zbliżonym poziomie, bowiem zysk brutto wykazał wielkość 2,6\%, zaś zysk netto 3,0\%. Wynik ten wynika przede wszystkim z tego, że przychody wykazały wzrost średnio o 1,2\%, natomiast koszty (-4,0 \%). Przychody rosły więc zdecydowanie szybciej niż koszty.

Poddając ocenie wskaźniki rentowności małych i średnich przedsiębiorstw, przeprowadzono analizę wskaźników rentowności: netto sprzedaży, brutto sprzedaży, aktywów netto i kapitału własnego netto. Wszystkie wymienione wskaźniki za okres badanych lat wykazały ujemne średnie tempo wzrostu oscylujące w przedziale od $-1,7$ do $-2,8$. Z kolei wskaźniki rentowności w każdym z badanych lat miały wartości dodatnie utrzymujące się na optymalnym poziomie, co może świadczyć o aktywności tej grup przedsiębiorstw, chociaż w zmieniającym się nieco tempie i zakresie.

Płynność MŚP została oceniona na postawie dwóch wskaźników: bieżącej i szybkiej płynności. Wskaźniki płynności bieżącej wykazały średnie tempo wzrostu dodatnie 0,1\%, mieszcząc się przy tym w optymalnym przedziale swoich wielkości.

Wskaźniki płynności szybkiej co prawda wykazały wielkości prawidłowe, jednak ich średnie tempo wzrostu było w granicach $-0,1 \%$.

Analizę zadłużenia małych i średnich przedsiębiorstw przedstawiono przy użyciu wskaźników: ogólnego zadłużenia, zadłużenia kapitałów własnych i zadłużenia długoterminowego.

Badane wskaźniki dowodzą, że MŚP w latach 2010-2016 prowadziły swoją działalność bez większych odchyleń oraz nieprawidłowości i mieściły się w optymalnych dla nich granicach. Również średnie tempo wzrostu wykazało wielkości dodatnie, mieszczące się w przedziale $0,2-1,5 \%$.

\section{Zakończenie}

Sektor MŚP na całym świecie odgrywa kluczową rolę w budowaniu wzrostu gospodarczego i innowacyjności we wszystkich branżach. Zrównoważony rozwój tego sektora ma kluczowe znaczenie dla rozwoju społeczno-ekonomicznego każdego państwa, ponieważ grupa małych i średnich przedsiębiorców tworzy najwięcej miejsc pracy na rynku, wykazuje się pomysłowością i zaangażowaniem, co też bardzo często owocuje wypracowaniem nowych, zaawansowanych technologii.

Przedsiębiorstwa $\mathrm{z}$ tego segmentu gospodarki przyczyniają się także do rozwijania rynku globalnego. Są jednak bardzo podatne na negatywne wpływy otoczenia gospodarczego i politycznego. Dlatego władze wielu państw, dostrzegając znaczenie i potencjał gospodarczy tej grupy przedsiębiorców tworzą programy wsparcia, spółki i instytuty badawcze zajmujące się analizą rozwoju i działania tego sektora. Wsparcie udzielane przez państwo pomaga utrzymać, a nawet zwiększyć zatrudnienie w nim.

Doświadczenia krajów wysoko rozwiniętych wskazują, że o sile i konkurencyjności ich gospodarek stanowią głównie firmy z sektora MŚP. Pozycja danego przedsiębiorstwa staje się bardziej ugruntowana, jeżeli na danym rynku zadziałają procesy globalizacyjne. Dzięki globalizacji jest możliwy lepszy rozwój jednostki. Pozytywnymi aspektami działań 
globalizacyjnych są: napływ kapitału zagranicznego, modernizacja linii produkcyjnych, zastosowanie nowoczesnych technologii, szybszy rozwój oraz zwiększenie inwestycji. Wskutek tych procesów następuje większy transfer towarów, usług oraz poszczególnych czynników produkcji w skali globalnej (Nesterowicz, 2013).

Uwarunkowania rozwoju sektora MŚP, przybliżenie jego pozytywnych cech oraz podkreślenie roli czynników sprzyjających odnoszeniu przez niego sukcesów pozwala określić ten sektor mianem aktywnego i dynamicznego, czego dowiodły przeprowadzone badania. Ujęcie sektora MŚP w taki sposób podkreśla jego ogromne znaczenie w zakresie tworzenia systemu ekonomicznego, formowania nowych uwarunkowań społecznych, ekonomicznych oraz politycznych.

Biorąc pod uwagę te wszystkie aspekty, należy spojrzeć na sektor MŚP pod kątem wydajności i efektywności wyników finansowych oraz źródeł, które zapewniają tym podmiotom zasilenie budżetu, by mogły w jeszcze lepszy sposób prosperować i się rozwijać. Małe i średnie przedsiębiorstwa swoją specyfiką, ograniczoną ilością kapitału i asortymentu oraz koniecznością ciągłego analizowania otoczenia konkurencyjnego wymagają od osób zarządzających dużego doświadczenia i umiejętności, co pozwala w tym miejscu podkreślić doniosłą rolę edukacji ekonomicznej w rozwoju przedsiębiorczości. Jednak mimo napotykanych barier, wyróżniają się one niezwykłą ekspresją wzrostową, czego potwierdzeniem są przedstawione w artykule wyniki finansowe.

Literatura

References

Gad, J. (2015). Analiza i ocena sytuacji finansowej przedsiębiorstwa. W: Ekonomia, finanse, prawo gospodarcze. Podręcznik dla sędziów i prokuratorów. Łódź: Wydawnictwo Uniwersytetu Łódzkiego, 69-77.

GUS. (2013). Działalność przedsiębiorstw niefinansowych w 2012 roku. Warszawa: Zakład Wydawnictw Statystycznych.

GUS. (2014). Działalność przedsiębiorstw niefinansowych w 2013 roku. Warszawa: Zakład Wydawnictw Statystycznych.

GUS. (2015). Działalność przedsiębiorstw niefinansowych w 2014 roku. Warszawa: Zakład Wydawnictw Statystycznych.

GUS. (2016). Działalność przedsiębiorstw niefinansowych w 2015 roku. Warszawa: Zakład Wydawnictw Statystycznych.

GUS. (2017). Działalność przedsiębiorstw niefinansowych w 2016 roku. Warszawa: Zakład Wydawnictw Statystycznych.

GUS. (2018). Działalność przedsiębiorstw niefinansowych w 2017 roku. Warszawa: Zakład Wydawnictw Statystycznych.

GUS. (2019). Działalność przedsiębiorstw niefinansowych w 2018 roku. Warszawa: Zakład Wydawnictw Statystycznych.

Kowalska, S. (2014). Przychody i koszty elementem zarządzania i wpływu na wynik finansowy - studium przypadku. Zeszyty Naukowe WSH Zarządzanie, 2, 277-287.

Kołodziej-Hajdo, M., Surowiec, A. (2011). Finansowanie projektów MŚP z funduszy unijnych. Korzyści i bariery. Zeszyty Naukowe Uniwersytetu Szczecińskiego. Finanse, Rynki Finansowe, Ubezpieczenia, 32, 535-547.

Matejun, M., Szymańska, K. (2012). Finansowanie i wspomaganie rozwoju firm sektora MŚP. Zarządzanie małą i średnią firmą w teorii i w ćwiczeniach. W: M. Matejun (red.), Zarządzanie mała $i$ średnią firma $w$ teorii i w ćwiczeniach. Warszawa: Difin, 207-253. 
Mikołajczyk B.(2007), Infrastruktura finansowa MSP w krajach Unii Europejskiej. Warszawa: Difin.

Nesterowicz, R. (2013). Ocena wyników działalności a możliwości wsparcia dla mikro i małych firm w Polsce. W: M.G. Woźniak (red.), Nierówności społeczne a wzrost gospodarczy. Rzeszów: Wydawnictwo Uniwersytetu Rzeszowskiego, 372-381.

PARP. (2019). Raport o stanie sektora małych i średnich przedsiębiorstw w Polsce 2011-2019. Warszawa: PARP.

Stawasz, E. (2006). Pojęcie i źródła finansowania MŚP. W: J. Bilski, E. Stawasz, Bariery w korzystaniu $z$ ustug bankowych $w$ finansowaniu działalności małych $i$ średnich przedsiębiorstw. Łódź: Wydawnictwo Uniwersytetu Łódzkiego, 16-17.

Timofiejuk, I. (1980a). Tablice średniego tempa wzrostu według metody ̣̣. Zeszyty Metodyczne, 41. Timofiejuk, I. (1980b). Stopa wzrostu gospodarczego . Metody liczenia. Warszawa: PWE. Ustawa $z$ dnia 6 marca 2018 roku Prawo przedsiębiorców. Dz.U. 2018, poz. 646.

Ustawa z dnia 2 lipca 2004 roku o swobodzie działalności gospodarczej. Dz.U. nr 173, poz. 1807.

Ustawa z dnia 29 września 1994 roku o rachunkowości. Dz.U. 1994, nr 121, poz. 591.

Renata Nesterowicz, doktor nauk ekonomicznych, adiunkt dydaktyczny Uniwersytetu Rzeszowskiego, Kolegium Nauk Społecznych, Instytutu Ekonomii i Finansów w Katedrze Finansów i Rachunkowości. Autorka licznych publikacji z zakresu finansów i rachunkowości. Jej zainteresowania naukowe to ocena wyników i dokonań małych i średnich przedsiębiorstw w Polsce.

Renata Nesterowicz, associated professor at the University of Rzeszów in the Faculty of Economics, Department of Finance. An author of numerous publications on finances and accounting. Her research interests include the evaluation of results and achievements of small and medium enterprises in Poland.

ORCID: https://orcid.org/0000-0002-0254-9633

\section{Adres/Address:}

Uniwersytet Rzeszowski

Instytut Ekonomii i Finansów

Katedra Finansów i Rachunkowości

ul. Ćwiklińskiej 2a

35-959 Rzeszów, Polska

e-mail: rbnester@onet.eu 